\title{
Hitting rock bottom: morphological responses of bedrock-confined streams to a catastrophic flood
}

\author{
M. Baggs Sargood ${ }^{1}$, T. J. Cohen ${ }^{1}$, C. J. Thompson ${ }^{2}$, and J. Croke ${ }^{3,4}$ \\ ${ }^{1}$ GeoQuEST Research Centre - School of Earth and Environmental Sciences, University of Wollongong, NSW, \\ 2522, Australia \\ ${ }^{2}$ Australian Rivers Institute, Griffith University, 170 Kessels Road, Nathan, QLD 4111, Australia \\ ${ }^{3}$ School of Geography, Planning and Environmental Management, University of Queensland, St Lucia, \\ Brisbane 4072, Australia \\ ${ }^{4}$ Department of Science, Information Technology, Innovation and the Arts, Queensland Government, Boggo \\ Road, Dutton Park, Brisbane 4102, Australia
}

Correspondence to: T. Cohen (tcohen@uow.edu.au)

Received: 16 October 2014 - Published in Earth Surf. Dynam. Discuss.: 9 December 2014

Revised: 27 April 2015 - Accepted: 10 May 2015 - Published: 5 June 2015

\begin{abstract}
The role of extreme events in shaping the Earth's surface is one that has held the interests of Earth scientists for centuries. A catastrophic flood in a tectonically quiescent setting in eastern Australia in 2011 provides valuable insight into how semi-alluvial channels respond to such events. Field survey data ( 3 reaches) and desktop analyses (10 reaches) with catchment areas ranging from 0.5 to $168 \mathrm{~km}^{2}$ show that the predicted discharge for the 2011 event ranged from 415 to $933 \mathrm{~m}^{3} \mathrm{~s}^{-1}$, with unit stream power estimates of up to $1077 \mathrm{~W} \mathrm{~m}^{-2}$. Estimated entrainment relationships predict the mobility of the entire grain-size population, and field data suggest the localised mobility of boulders up to $4.8 \mathrm{~m}$ in diameter. Analysis of repeat lidar data demonstrates that all reaches (field and desktop) were areas of net degradation via extensive scouring of coarse-grained alluvium with a strong positive relationship between catchment area and normalised erosion $\left(R^{2}=0.72-0.74\right)$. The extensive scouring in the 2011 flood decreased thalweg variance significantly removing previous step pools and other coarse-grained in-channel units, forming lengths of plane-bed (cobble) reach morphology. This was also accompanied by the exposure of planar bedrock surfaces, marginal bedrock straths and bedrock steps. Post-flood field data indicate a slight increase in thalweg variance as a result of the smaller 2013 flood rebuilding the alluvial overprint with pool-riffle formation. However, the current form and distribution of channel morphological units does not conform to previous classifications of bedrock or headwater river systems. This variation in postflood form indicates that in semi-alluvial systems extreme events are significant for re-setting the morphology of in-channel units and for exposing the underlying lithology to ongoing erosion.
\end{abstract}

\section{Introduction}

\subsection{Importance of bedrock channel morphology and processes}

Bedrock or semi-alluvial channels (see Meshkova et al., 2012) received little attention in the literature for much of the 20th century due to the concentration of human interests in lowland alluvial valleys (Halwas and Church, 2002; Toone et al., 2014). The relatively recent recognition of steep headwa- ter channels as critical habitats and sediment sources, as well as their role in landscape evolution, has encouraged research in recent decades, with a particular focus on process-based morphology (Montgomery and Buffington, 1997), the nature and rates of bedrock incision (Sklar and Dietrich, 1998; Tinkler and Wohl, 1998), and the numerical modelling of sediment transport and bedrock incision (see Turowski et al., 2007, 2009; Lague, 2010). Such river channels often comprise a mixture of alluvial and non-alluvial features but are 
delineated by the high sediment transport capacity of flows relative to sediment supply (Howard et al., 1994). The morphology of most fluvial channels is the result of hierarchical arrangements of alluvial material into bedforms or channel units which form sequences which characterise the reachscale morphology (Shields, 1936). This reach morphology is a function of variables such as geology, climate and landuse which drive the channel topography and sediment characteristics, river discharge and the character of riparian vegetation (Buffington et al., 2003).

Recent interest in the process-based morphology of bedrock channels has led to the creation of a number of morphological classification models for steep mountain streams (Wohl and Merritt, 2001). An important contribution by Montgomery and Buffington (1997) outlined a framework for reach-scale classification of mountain streams into visually identifiable and physically distinct categories which has been applied and adapted by a number of subsequent researchers to describe bedrock channels in specific catchments (Halwas and Church, 2002; Golden and Springer, 2006; Thompson et al., 2006; Wohl and Merritt, 2008). The Montgomery and Buffington (1997) classification includes an idealised downstream progression from bedrock and colluvial zones into fluvial-dominated zones with a progression from cascade, step-pool, plane-bed, pool-riffle and into duneripple reach morphologies (Fig. 1). The most robust predictors of bedrock channel morphology are the relationship between slope and drainage area, sediment supply and sediment transport capacity ratios, and channel geometry (Montgomery and Buffington, 1997; Thompson et al., 2006; Wohl and Merritt, 2008). The state of a channel at any given time is strongly influenced by the disturbance regime and the lagtime since the most recent disturbance (Montgomery and Buffington, 1997). This morphological response to disturbance highlights the need to investigate the channel morphology of stream networks which have recently undergone an extreme disturbance and determine whether a change in process domain has occurred and the nature or trajectory of such change. As such, the specific objectives of this study are to (1) quantify the morphological response of bedrock channels to an extreme event, (2) determine whether a directional change in process domain occurred and (3) to assess the removal of coarse-grained cover and potential bedrock erosion and present an evolutionary model for semi-alluvial channels that are subject to such large-magnitude, low-frequency events. In post-orogenic terrain where bedrock is rarely exposed in the channel network the frequency of such rare events and their effectiveness is likely to be a key factor in determining long-term bedrock incision rates.

\subsection{Response of bedrock channels to disturbance}

The geomorphic effectiveness of floods describes the ability of an event to affect the shape or form of the channel morphology or the landscape (Wolman and Gerson, 1978).

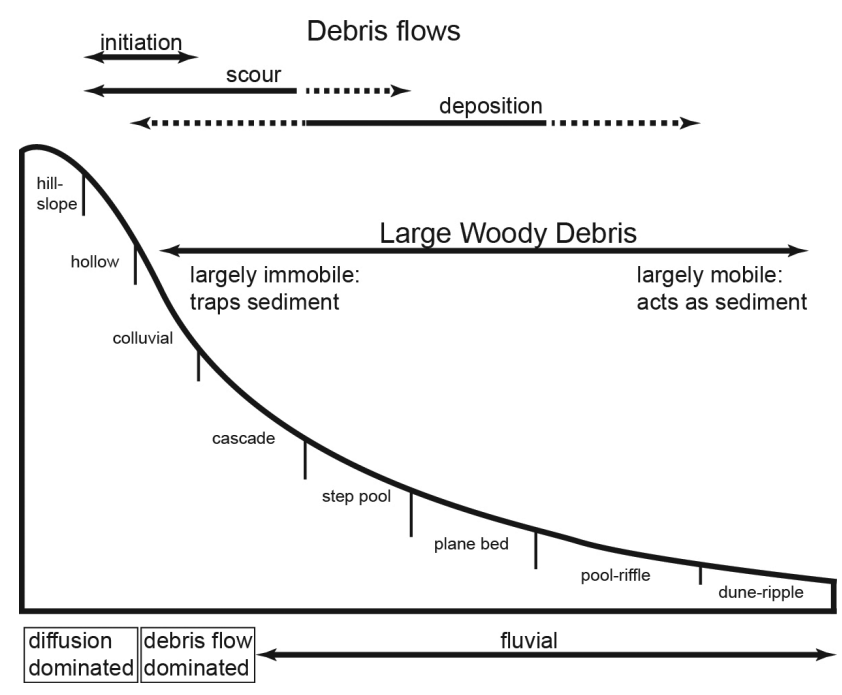

Figure 1. Idealised long profile downslope through the channel network showing distribution of channel types and controls on channel processes (from Montgomery and Buffington, 1997).

In fluvial systems, this change primarily occurs through the transportation of sediment and subsequent rearrangement, destruction or creation of channel units. The morphological adjustment to floods can result in wholesale channel reorganisation or minor changes to channel dimensions which do not affect overall processes (Thompson et al., 2006), depending on the magnitude and frequency of the event. Geomorphic effectiveness is a function of the size and duration of the disturbance and the inherent resistance of the system in terms of boundary conditions (Wohl, 2007). Bedrock channels in small catchments typically have highly variable flow regimes and resistant boundary conditions. Lowfrequency, high-discharge floods are the "geomorphically effective" floods, as larger flows are required to mobilise sediment and propagate bedrock erosion and incision (Wolman and Miller, 1960; Costa and O'Connor, 1995; Baker and Kale, 1998; Milan, 2012). Due to the fact that individual settings exhibit different characteristics in terms of boundary resistance and the frequency of effective processes and rates of recuperative processes, the magnitude of a discharge is only one factor in determining the extent of changes caused by an event (Costa, 1974). The literature regarding geomorphic responses to disturbance indicates that floods of similar scale and frequency can produce very different changes to channel morphology (Costa and O'Connor, 1995) due to antecedent conditions such as flood ordering and timing, and internal factors such as condition of riparian vegetation and/or presence of large wood or log jams.

Baker (1977) highlights the role of flood variability in determining morphological channel response to flooding. The range of flood magnitudes experienced by a stream is a strong predictor of the degree of geomorphic impact of floods between different settings. The high variability of discharges 


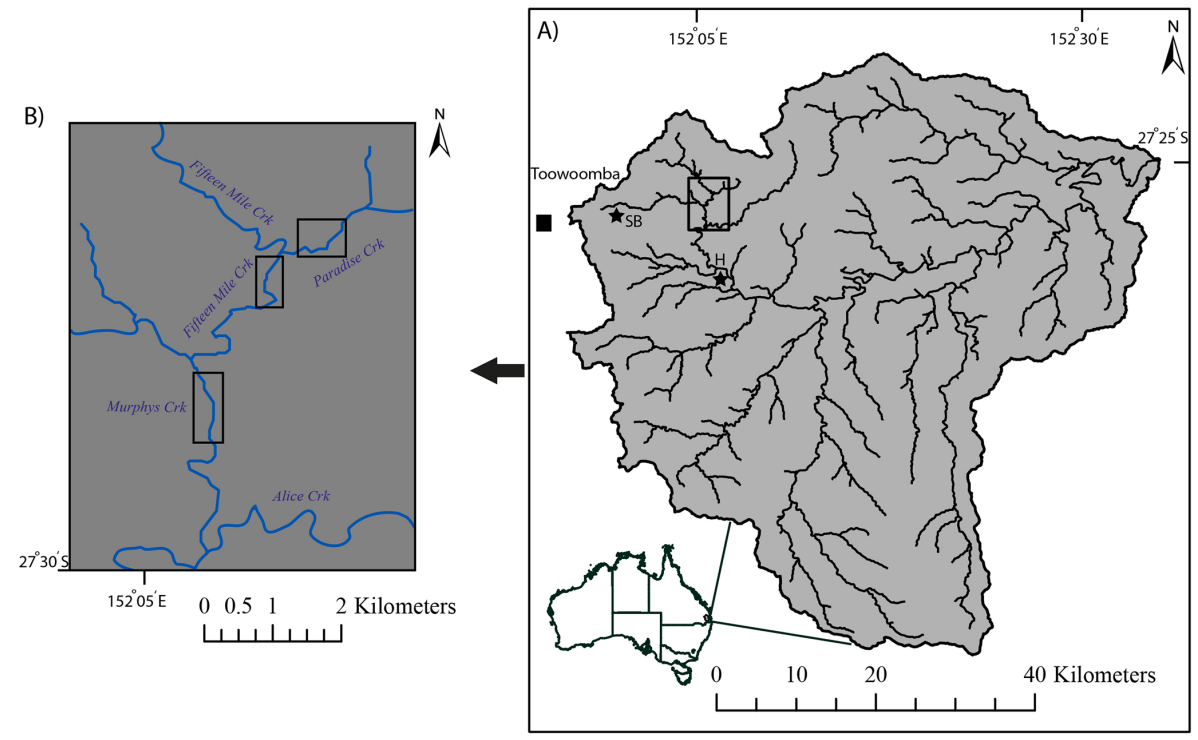

Figure 2. (a) Location of the Lockyer Valley catchment in southeast Queensland, Australia, including the location of the two gauges used in the study (stars): Spring Bluff (SB) and Helidon (H) and location of the study area (boxed region). (b) Study area in the upper valley showing the three main creeks utilised in the field study.

typical of headwater drainage networks creates a system which maintains relatively uniform structure during normal flow periods and responds catastrophically to large, infrequent events (i.e. > 100-year average recurrence interval ARI) (Miller, 1995; Jansen, 2006; Wohl, 2007). The response of semi-alluvial channels to geomorphically effective floods is critical for a robust understanding of both process-based morphology in such settings and catchment-wide effects of flooding, as the morphology of upper catchment drainage networks has a significant impact on the nature of downstream disturbance propagation.

\subsection{Role of large floods in channel evolution}

As rare, large-magnitude events operate as the geomorphically effective discharges in steep montane drainage networks, they inherently play a major role in the long-term morphology and evolution of channels in such settings. Large flood events can fundamentally alter the sediment supply and transport capacity of such systems, which ultimately dictates channel form and stability. As such, large floods can cause instability through either aggradation or erosion of coarsegrained alluvium (Turowski et al., 2013). In eastern Australia this ratio of either aggradation or erosion of coarse-grained alluvium and thus the morphological stability and evolution of such systems (Nanson, 1986; Thompson et al., 2006) may well be influenced by the extreme hydrological variability (see Finlayson and McMahon, 1988) that the region experiences. The potential role of such hydrological variability could indicate that in some settings river channels can adjust to conditions set by major floods and subsequently maintain a flood-dominated morphology (Fuller, 2008; Hickin,
2009). The high spatial resolution of modern lidar imaging allows the analysis of such morphological changes through the mapping of in-channel features, creation of digital elevation models (DEMs) and change assessment through rendering of multi-temporal DEMs of difference (DODs) (Croke et al., 2013). Recent studies highlight the range of applications for lidar analysis at different scales, from reach-scale to catchment-wide processes (Charlton et al., 2003; Croke et al., 2013; Grove et al., 2013). Catchments for which lidar data record pre-disturbance and post-disturbance morphology present a good opportunity to assess changes to processes and morphology as a result of disturbance on a range of scales, from discrete channel units to basin-wide trends. The presence of pre- and post-2011 flood lidar in the Lockyer Valley, Queensland, allows for such an assessment. Previous studies in the region have focussed on the alluvial reaches (or variations in responses between confined and unconfined reaches) and bank erosion within agricultural and semi-agricultural settings (Croke et al., 2013; Grove et al., 2013; Thompson and Croke, 2013). In contrast, the main aim of this study is to assess the channel response in forested bedrock-confined settings to an extreme event and examine the current channel based on existing morphological classification systems by utilising multi-temporal lidar DEMs and field surveys.

\section{Regional setting}

\subsection{Southeast Queensland}

Southeast Queensland has a highly variable climate, and the long-term precipitation patterns of eastern Australia are in- 
fluenced by global systems including the El Niño-Southern Oscillation (ENSO), the subtropical ridge (STR) and the Indian Ocean sea surface temperature patterns (Kirkup et al., 1998). The temporal variability of such climatic drivers leads to high inter-annual rainfall variability as well as decadal trends of above-average and below-average rainfall across eastern Australia, described in the literature as floodand drought-dominated regimes (Erskine and Warner, 1988). This temporal variability in rainfall manifests in high streamflow variability in many parts of eastern Australia, particularly northern New South Wales and southern Queensland (Rustomji et al., 2009).

\subsection{Upper Lockyer catchment}

The Lockyer Valley lies east of Toowoomba and west of Brisbane in southeast Queensland, Australia (Fig. 2), and the catchment has a drainage area of $2890 \mathrm{~km}^{2}$, comprising approximately a quarter of the Brisbane River catchment (Croke et al., 2013). The alluvial lowlands of the Lockyer Valley are one of the most productive agricultural regions of Australia, being intensively cultivated for horticulture whilst the upper Lockyer region is dominated by grazing for livestock. The southern and western extents of the catchment are steep and forested, reaching elevations of up to $700 \mathrm{~m}$ above sea level (Australian Height Datum, AHD). The climate of the Lockyer Valley is sub-humid, subtropical and strongly seasonal, with $65-70 \%$ of total rainfall occurring between October and March, in part due to higher precipitation intensities associated with summer storms generated by subtropical lows. Average annual rainfall in the upper Lockyer region is $\sim 800 \mathrm{~mm}$ (at Helidon; Fig. 2). The study area is in post-orogenic terrain located on the eastern side of the Great Dividing Range (Fig. 2). The lithology of the region is dominated by sedimentary and metamorphosed sedimentary rocks of Jurassic-Triassic and Permian origin, respectively (Geological Survey of Queensland, 2011). The streams of the region are situated in steep, narrow, bedrock-constrained semi-alluvial channels with a discontinuous cover of coarsegrained alluvium or colluvium overlying the bedrock.

\subsection{Flooding in the Lockyer catchment}

Catastrophic flooding occurred in the Lockyer Catchment resulting in extensive geomorphic change and damage to infrastructure and the loss of human life on 10 and 11 January 2011. The flooding was preceded by months of recordbreaking rainfall across southeast Queensland (Bureau of Meteorology, 2011). The extended and consistent nature of this rainfall resulted in the saturation of the Lockyer catchment, effectively creating run-off conditions where rainfall could not infiltrate the soil column and was transmitted directly to streams. On 10 January, a low-pressure system moved inland over the catchment, colliding with upper level and monsoon troughs (BMT WBM Pty Ltd, 2011) and in- tensified under orographic uplift in the north and west of the basin. These atmospheric conditions resulted in extreme rain intensities of up to $\sim 150 \mathrm{~mm}$ in $2 \mathrm{~h}$ in the headwater tributaries of Fifteen Mile and Alice Creek sub-catchments (Fig. 2), with an annual exceedance probability for rainfall of greater than 2000 years over all timescales from 1 to $48 \mathrm{~h}$ at Helidon (Fig. 2, SEQ Water, 2011). This heavy precipitation, on top of the wettest December on record, played a disproportionate role in the flooding due to the high intensity of localised rainfall and the steep-confined nature of the headwater channels which rapidly transmitted this water downstream. The result of this heavy precipitation was an $8 \mathrm{~m}$ rise in the hydrograph in $30 \mathrm{~min}$, recorded at the Helidon gauge (Fig. 2).

A second heavy rainfall event occurred in the summer of 2013 across coastal Queensland which resulted in flooding in the Lockyer and Brisbane catchments, with 190-290 mm of rainfall recorded over $48 \mathrm{~h}$ between 22 and 28 January $(\mathrm{Bu}-$ reau of Meteorology, 2013). While flooding throughout the Lockyer Valley was extensive, geomorphic change and infrastructure damage were less catastrophic than 2011. The characteristics of the 2011 flood and flood frequency calculations for the upper Lockyer are presented in Table 1. Log Pearson III analysis returned an average recurrence interval (ARI) for the 2011 flood of $\sim 60$ year at Spring Bluff and 45 years at Helidon, which is much less than previous estimates, highlighting that the estimated return intervals are heavily dependent on whether data up to 2013 are included in the analysis. In contrast the 2013 flood represented an ARI frequency of 8 and 5 years for Spring Bluff and Helidon, respectively.

\section{Methods}

\subsection{Site selection and field survey}

Selection of potential study reaches was carried out using a geographical information system. Using a $1 \mathrm{~m}$ DEM, aerial photography and a 1:100000 digital surface geology map, three reaches of similar lithology and varying contributing drainage area and slope were selected for field survey which were accessible by road. An additional 10 reaches were selected for spatial analysis based on the same criteria. Channel "reaches" are sections of channel reaches of at least 10 channel widths in length, which represent sections of a stream containing a sequence of channel units throughout which morphology and gradient are relatively constant (Montgomery and Buffington, 1997; Wohl and Merritt, 2001). The average reach length surveyed was $\sim 1200 \mathrm{~m}$.

Study reaches were surveyed along the low-flow channel using differential GPS survey equipment (Trimble R7 and R8 GNSS system) in April 2013. A lack of base station static data for each of the surveys prevented post-processing, requiring the 2013 field data to be normalised to the lidar data sets (see Sect. 3.3). To measure thalweg variance a thalweg 
Table 1. Flood characteristics of the 2011 flood, showing calculated flash flood magnitude index (FFMI; standard deviation of the log 10 of the annual maximum series) and the average recurrence interval (ARI) for the 2011 event for data up to 2010 and 2013 inclusive; 2010 values from Thompson and Croke (2013). $Q_{p}$ : maximum recorded flow; MAF: mean annual flow. See Fig. 2 for gauge locations.

\begin{tabular}{lrrrr}
\hline & \multicolumn{2}{c}{2010 Data } & \multicolumn{2}{c}{2013 Data } \\
\cline { 2 - 5 } & $\begin{array}{r}\text { Spring Bluff } \\
(143219 \mathrm{~A})\end{array}$ & $\begin{array}{r}\text { Helidon } \\
(143203 \mathrm{C})\end{array}$ & $\begin{array}{r}\text { Spring Bluff } \\
(143219 \mathrm{~A})\end{array}$ & $\begin{array}{r}\text { Helidon } \\
(143203 \mathrm{C})\end{array}$ \\
\hline Length of record (years) & 31 & 24 & 34 & 27 \\
Catchment area $\left(\mathrm{km}^{2}\right)$ & 18 & 357 & 18 & 357 \\
FFMI & 0.88 & 0.7 & 0.95 & 1.40 \\
$Q_{p}$ gauged $\left(\mathrm{m}^{3} \mathrm{~s}^{-1}\right)$ & 361.5 & 3642 & 361.5 & 3642 \\
Specific peak discharge $\left(\mathrm{m}^{3} \mathrm{~s}^{-1} \mathrm{~km}^{-2}\right)$ & 20.08 & 11.76 & 20.08 & 11.76 \\
$Q_{p} / \mathrm{MAF}$ & 15.1 & 10.9 & 15.1 & 10.9 \\
ARI (yr) & $\sim 2000$ & 100 & 59 & 45 \\
\hline
\end{tabular}

longitudinal profile was measured in each of three representative field reaches with in-channel units mapped along with the presence, location and height of flood marks from the 2011 flood, including tree scarring and flood debris on the channel boundary. Cross sections were surveyed at the upstream and downstream extent of the study reaches and grainsize data were collected using a modified Wolman (1954) line intersect method with grain size determined by the measurement of 100 sediment particles per bar (measured to a minimum of $2 \mathrm{~mm}$, given known bias against selecting finer particles; Bunte and Abt, 2001)

\subsection{Entrainment threshold calculations}

Due to the lack of stream gauges in the study area, the magnitude of the 2011 flood in the three field reaches has been estimated using the Manning-Strickler equation. This was based on cross-sectional surveys in each of the three reaches (undertaken in the 2013 field season and assuming no gross change in cross section between January 2011 and March 2013) along with estimated flood levels for two cross sections per reach and estimated reach-averaged water surface slope for the 2011 flood (based on flood scars). The estimation of Manning's $n$ for hydrological calculations characterising the 2011 flood event was carried out using the Meyer-Peter and Müller (1948) equation, which accounts for the increased turbulence of deep-water flow associated with large flood events in mountain channels.

$n=\frac{\left(\left(D_{90}\right)^{1 / 6}\right)}{26.0}$,

where $D_{90}$ is particle size representing the 90th percentile of bedload.

The roughness estimates and field channel survey data were used to calculate values for predicted discharge, shear stress, and stream power with values of discharge constrained in the most downstream reach by previous basin-scale modelling (see Thompson and Croke, 2013). This basin-scale modelling provides an important independent check against the validity of the chosen $n$ values used for the final estimates.

Calculation of predicted entrainment thresholds for the sediment fractions of the three study reaches was made using a range of flume-based and field-based equations in order to test their applicability in catastrophic floods to such settings. The Shields parameter (Shields, 1936) is a flume-based calculation which describes a "universal" threshold for the initiation of movement of bedload according to shear stress and grain size.

$\tau_{*}=\frac{\tau_{\mathrm{c}}}{\left(\gamma_{\mathrm{s}}-\gamma\right)} D$,

where $\tau_{\mathrm{c}}$ is critical shear stress, $\gamma_{\mathrm{s}}$ is the specific weight of bed material, $\gamma$ is the specific weight of water, $D$ is the bed material particle diameter and $\tau_{*}$ is the dimensionless Shields parameter.

Komar and Carling (1991) propose a modified shear-stress equation based on the use of reference particles to predict the entrainment of bed material in steep natural channels with poorly sorted, coarse bedloads.

$\tau_{\mathrm{ci}}=\tau_{\mathrm{c} 50}^{*}\left(\gamma_{\mathrm{s}}-\gamma\right) D_{\mathrm{i}}^{0.3} D_{50}^{0.7}$,

where $\tau_{\mathrm{ci}}$ is critical shear stress for the particle of interest to move, $\tau_{\mathrm{c} 50}^{*}$ the dimensionless Shields parameter for $D_{50}, D_{\mathrm{i}}$ is the diameter of the particle size of interest and $D_{50}$ is the diameter of the median particle size of the channel bed.

The Bathurst (1987) equation uses a unit discharge approach to predict entrainment thresholds in steep mountain channels with coarse bed materials, accounting for the effects of exposure and protection in mixed-size sediment stores.

$q_{\mathrm{c}}=0.15 g^{0.5} D^{1.5} S^{-1.12}$, 
where $q_{\mathrm{c}}$ is critical water discharge per unit width, $g$ is acceleration due to gravity, $D$ is the diameter of the particle size of interest and $S$ is the slope.

$q_{\mathrm{ci}}=q_{\mathrm{cr}}\left(\frac{D_{\mathrm{i}}}{D_{\mathrm{r}}}\right)^{b}$,

where $q_{\mathrm{ci}}$ is critical unit discharge for the movement of particles of size $D_{\mathrm{i}}, q_{\mathrm{cr}}$ is critical unit discharge for the reference particle size $D_{\mathrm{r}}$ and $b$ is an exponent (derived from Eq. 6):

$b=1.5\left(\frac{D_{84}}{D_{16}}\right)^{-1}$.

\subsection{Spatial analysis}

Spatial analysis was undertaken using georeferenced field survey data and lidar-derived DEMs flown in 2010 (preflood) and 2011 (post-flood). The pre-flood lidar was captured with a Leica ALS50-11 airborne laser scanner at an average point density of 2 points $\mathrm{m}^{-2}$, whereas the post-flood lidar was captured using a Riegl LMS-Q680 airborne laser scanner at approximately 4 points $\mathrm{m}^{-2}$. In both cases data were filtered to remove any visually obvious anomalies before deriving a triangular irregular network. From this a $1 \mathrm{~m}$ DEM was produced for both time steps.

DEMs of difference (DoDs) were created based on the subtraction of one DEM from the other and applying a minimum level of detection $\left({ }_{\min } \mathrm{LoD}\right)$ threshold approach (following Wheaton et al., 2010). Previous research in the region, using the same lidar data, has applied a single standard deviation error value of $\pm 0.23 \mathrm{~m}$ propagated from the DEMs (Croke et al., 2013). This was based on validation of the lidar data with known survey points which yielded a root-meansquare error of $0.08 \pm 0.15 \mathrm{~m}$ (standard deviation of error SDE) for the 2010 data and $0.08 \pm 0.17 \mathrm{~m}$ for the 2011 data (see Croke et al., 2013, for error quantification methods). Croke et al. (2013) use a probabilistic approach to assess the uncertainty in their DoD and prescribe a value $(95 \%$ confidence interval) of $\pm 0.44 \mathrm{~m}$. We utilise both of these error estimates and undertake and present ${ }_{\min } \mathrm{LoD}$ analyses using both values, in addition to a probabilistic approach.

In order to integrate the 2013 field data long profile data with the 2010 and 2011 lidar it was necessary to normalise the 2013 field survey point data to the 2011 lidar-derived DEM. This normalisation was done by calculating the vertical displacement of $20 \%$ of the field survey points per reach, which were assumed not to have changed between 2011 and 2013, such as prominent bedrock ledges on the channel margin. The mean displacement was then applied to all field-derived point data. Multi-temporal longitudinal profiles and cross sections of the study reaches were derived from the 2010 and 2011 DEMs and plotted with field survey points from 2013. We cannot quantify the reliability of this normalisation technique, and estimates of vertical changes in the long profiles must take into account the previously described errors. As such, we take a conservative estimate where changes within $\pm 0.44 \mathrm{~m}$ are considered below the level of detection. Vertical variability in the long profile data was quantified for each data set by applying a linear regression to the longitudinal profile data and calculating residuals. Cross-sectional area values were calculated by determining the maximum height of channel-marginal sedimentary units in the pre-flood data (2010) and calculating area below this height for pre-flood and post-flood data. To determine the mass flux of sediment in these semi-alluvial settings, a volumetric analysis was undertaken between the pre-flood and post-flood DEMs for an additional 10 reaches $(\sim 1 \mathrm{~km}$ in length), in the same lithology with catchment areas ranging from 0.5 to $168 \mathrm{~km}^{2}$. We present normalised erosion indices where thresholded net volumetric change per reach is divided by total reach area $\left(\mathrm{m}^{3} \mathrm{~m}^{-2}\right)$. We cannot constrain the degree of bedrock erosion vs. cover removal in the three field reaches, and we assume that net volumetric change is dominated by the removal of the coarse-grained cover (expanded below).

\section{Results}

\subsection{Sediment entrainment in an extreme event}

Peak discharge for the 2011 flood, based on flood scarring and estimated Manning's $n$ values equivalent to those used by Thompson and Croke (2013) in their catchmentwide modelling for the same event, yields discharge values ranging from 415 to $933 \mathrm{~m}^{3} \mathrm{~s}^{-1}$, shear stress values up to $388 \mathrm{~N} \mathrm{~m}^{-2}$ and cross-sectional averaged unit stream power of $1077 \mathrm{~W} \mathrm{~m}^{-2}$ (Table 2) for an event that was 6-8 $\mathrm{m}$ flow depth. All three entrainment approaches predict the mobilisation of the $D_{50}$ in each of the reaches in the 2011 flood, but with the Shields parameter predicting insufficient competence to transport the $D_{\max }$ (Table 3). Field observations and aerial imagery show that the entire bedload fraction was mobilised during the 2011 flood in each of the three reaches, indicated by the extensive channel stripping and removal of an extensive coarse-grained cover with the transport of boulders of at least $1.67 \mathrm{~m}$ in diameter ( $D_{\max }$ at Murphys Creek, Fig. 2, Table 2). Anecdotal evidence and field observations suggest that clasts up to $4.82 \mathrm{~m}$ were mobilised during the 2011 flood (Fig. 3). The Komar and Carling (1991) approach and the Bathurst (1987) equation both successfully predict the mobilisation of the entire sediment fraction during the 2011 flood (Table 3). Magnitudes of the 2013 flood in three field reaches could not be estimated due to insufficient depth control (e.g. lack of flood debris). 
Table 2. Reach characteristics and calculated discharge, stream power and shear stress for the 2011 flood in each of the three field reaches.

\begin{tabular}{|c|c|c|c|c|c|c|c|c|c|c|c|c|}
\hline & $\begin{array}{r}\text { Area } \\
\left(\mathrm{km}^{2}\right)\end{array}$ & $\begin{array}{r}\text { Slope } \\
\left(\mathrm{m} \mathrm{m}^{-1}\right)\end{array}$ & $\begin{array}{r}\text { Channel } \\
\text { width }(\mathrm{m})\end{array}$ & $\begin{array}{r}D_{16} \\
(\mathrm{~mm})\end{array}$ & $\begin{array}{r}D_{50} \\
(\mathrm{~mm})\end{array}$ & $\begin{array}{r}D_{84} \\
(\mathrm{~mm})\end{array}$ & $\begin{array}{r}D_{95} \\
(\mathrm{~mm})\end{array}$ & $\begin{array}{l}D_{\text {Max }} \\
(\mathrm{mm})\end{array}$ & $\begin{array}{r}\text { Manning's } \\
n\end{array}$ & $\begin{array}{r}Q \\
\left(\mathrm{~m}^{3} \mathrm{~s}^{-1}\right)\end{array}$ & $\begin{array}{r}\omega \\
\left(\mathrm{W} \mathrm{m}^{-2}\right)\end{array}$ & $\left(\mathrm{Nm}^{-2}{ }^{\tau}\right)$ \\
\hline Murphys Creek & 168 & 0.005 & 70 & 29 & 85 & 310 & 500 & 1670 & 0.1 & 897 & 690 & 286 \\
\hline Fifteen Mile Creek & 89 & 0.008 & 70 & 21 & 85 & 288 & 505 & 1088 & 0.1 & 933 & 1077 & 388 \\
\hline Paradise Creek & 26 & 0.011 & 76 & 26 & 67 & 170 & 236 & 492 & 0.1 & 415 & 616 & 277 \\
\hline
\end{tabular}

Table 3. Results of flow competence equations for the 2011 flood; bold values indicate that sediment entrainment is not predicted. $\tau_{\mathrm{c}}$ : critical shear stress $\left(\mathrm{N} \mathrm{m}^{-2}\right) ; q_{\mathrm{ci}}$ : critical unit discharge for the movement of particles of size $D$.

\begin{tabular}{lrrr|rrr|rrr}
\hline & \multicolumn{3}{c}{ Shields (1936) } & \multicolumn{3}{c|}{ Komar and Carling (1991) } & \multicolumn{3}{c}{ Bathurst $(1987)$} \\
\hline & $\tau_{\mathrm{c}}\left(D_{50}\right)$ & $\tau_{\mathrm{c}}\left(D_{95}\right)$ & $\tau_{\mathrm{c}}\left(D_{\mathrm{MAX}}\right)$ & $\tau_{\mathrm{c}}\left(D_{50}\right)$ & $\tau_{\mathrm{c}}\left(D_{95}\right)$ & $\tau_{\mathrm{c}}\left(D_{\mathrm{MAX}}\right)$ & $q_{\mathrm{ci}}\left(D_{50}\right)$ & $q_{\mathrm{ci}}\left(D_{95}\right)$ & $q_{\mathrm{ci}}\left(D_{\mathrm{MAX}}\right)$ \\
\hline Murphys Creek & 68.79 & $\mathbf{4 0 4 . 9 1}$ & $\mathbf{1 3 5 1 . 5 7}$ & 71.54 & 114.62 & 174.81 & 3.95 & 5.07 & 6.01 \\
Fifteen Mile Creek & 68.79 & 408.83 & $\mathbf{8 8 0 . 5 5}$ & 71.54 & 111.51 & 153.72 & 2.49 & 3.03 & 3.29 \\
Paradise Creek & 54.22 & 191.32 & $\mathbf{3 9 8 . 1 9}$ & 56.39 & 77.15 & 102.56 & 1.22 & 1.63 & 1.92 \\
\hline
\end{tabular}
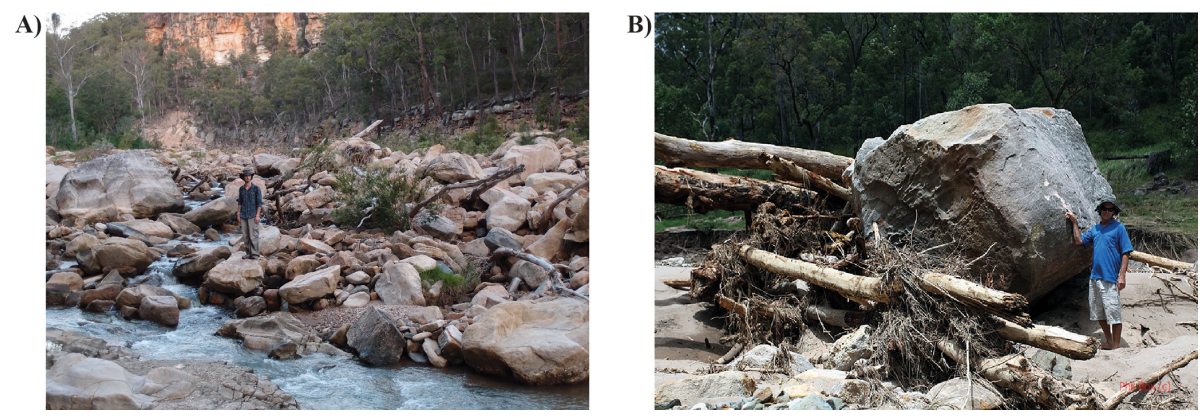

Figure 3. Photographs of large particles mobilised in the 2011 flood event. (a) Boulder bar at Fifteen Mile Creek (Fig. 2) with $D_{50}$ of $2325 \mathrm{~mm}$. (b) Large boulder with $b$ axis of $4820 \mathrm{~mm}$ at Paradise Creek (Fig. 2).
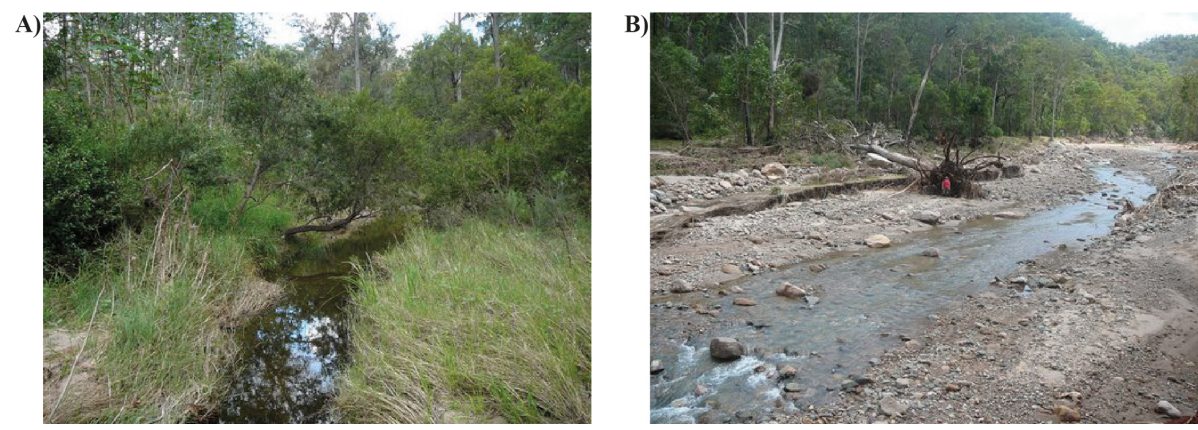

Figure 4. (a) Pre-flood (2010) and (b) post-flood (2011) photography of Paradise Creek (Fig. 2) in the upper Lockyer Valley, showing catastrophic channel stripping and widening. 


\subsection{Morphological response of the 2011 and 2013 floods}

Repeat photographs (Fig. 4), aerial imagery and lidar indicate a channel mantled in coarse-grained alluvium in the study reaches prior to the 2011 flood, with narrow, stable lowflow channels and densely vegetated coarse-grained bars. Longitudinal profiles from pre-flood lidar show a high degree of longitudinal variability, with alternating sequences of riffles/steps and pools in the three reaches and deep, narrow low-flow channels (Figs. 4 and 5). Lidar-generated preflood cross-sectional morphology also demonstrates the presence of channel marginal features, presumed to be vegetated coarse-grained bars or benches.

The 2011 flood resulted in catastrophic channel stripping with the total destruction of channel units and the removal of in-channel and riparian vegetation (Fig. 4b). The post-flood lidar demonstrates large decreases in longitudinal variance with the stripping of coarse alluvium and the removal of the small inner channel via the erosion of in-channel or channel marginal sediment stores (Fig. 4b). The channel was lowered to bedrock along segments of the three reaches exhuming bedrock steps, removing coarse-grained bedforms, filling in existing pools, and producing longitudinal profiles in which the bedrock steps now represent major areas of significant channel bed variability (Fig. 5a-c). Significant erosion of alluvium is evident throughout the three reaches, with postflood cross sections taking on a uniformly wide trapezoidal shape (Fig. 6) with channel cross-sectional area expanding by $66-123 \%$ (Table 4 ).

The 2013 flood represents an event with a much smaller ARI than the 2011 flood with an estimated recurrence interval in the upper catchment of $<10$ years. Separating the morphological impacts of the flood of 2013 vs. that of 2011 is difficult. Nevertheless, field survey data following this smaller event demonstrate increased variability in the longitudinal profiles since 2011, with small accumulations of sediment forming cobble-gravel riffles and the excavation and scour of a number of shallow pools (Fig. 5a-c). The 2013 flood event represented a discharge which resulted in considerable sediment redistribution throughout the upper Lockyer catchment, evident in the re-formation of in-channel bars and riffles; however flow depths were most likely $<3 \mathrm{~m}$, in contrast to twice that in the 2011 flood. Cross sections from the field survey in 2013 show small amounts of sediment accretion adjacent to the low flow channel with the establishment of primary colonising species and what appears to be a recovery towards a more variable and stable morphology.

\subsection{Spatial analysis of reach-scale volumetric change}

To determine the mass flux of sediment in these headwater settings, a volumetric analysis was undertaken for the additional 10 reaches ( $\sim 1 \mathrm{~km}$ in length) in the same lithology with catchment areas ranging from 0.5 to $168 \mathrm{~km}^{2}$. Analysis
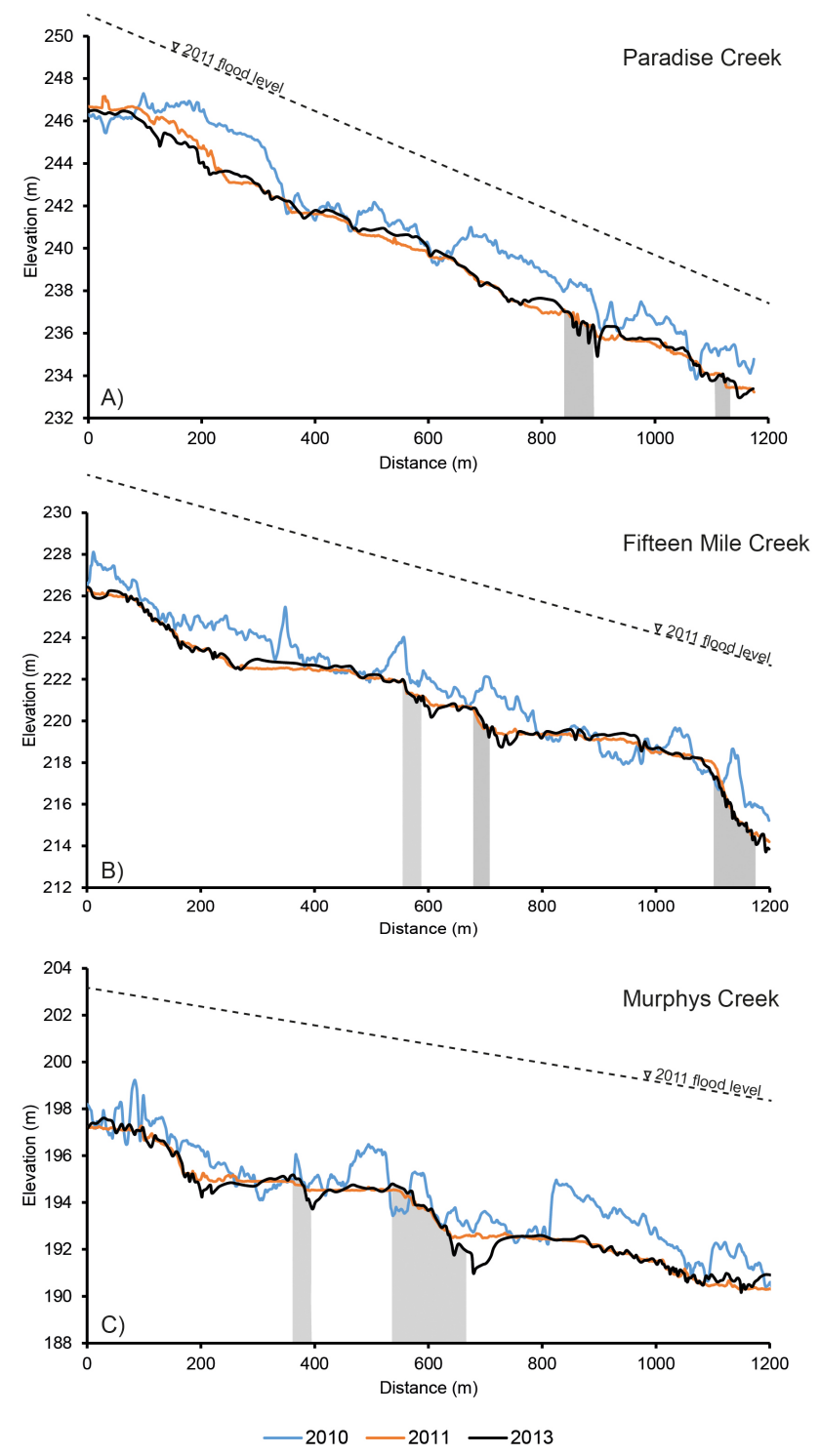

Figure 5. Longitudinal profiles of the three field sites: (a) Paradise Creek, (b) Fifteen Mile Creek and (c) Murphys Creek. Derived from 2010 and 2011 lidar (pre- and post-2011 flood) and 2013 normalised DGPS thalweg profile (post-2013 flood). Dashed black line represents average water surface profile for the January 2011 flood based on DGPS elevations of flood marks. Grey shaded bars in each profile highlight exhumation of bedrock steps in the 2011 flood.

of volumetric change across the reaches, which vary in slope and contributing area, shows a number of clear trends in the degree and location of erosion and deposition in the semialluvial reaches of the upper Lockyer during the 2011 flood. Figure 6 demonstrates the nature of erosion and deposition within one of the three field reaches - Murphys Creek. The relatively straight nature of this reach resulted in a uniform pattern of channel stripping concentrated through the centre of the bedrock channel, with deposition along the channel margins in discontinuous pockets. All of the reaches (field 


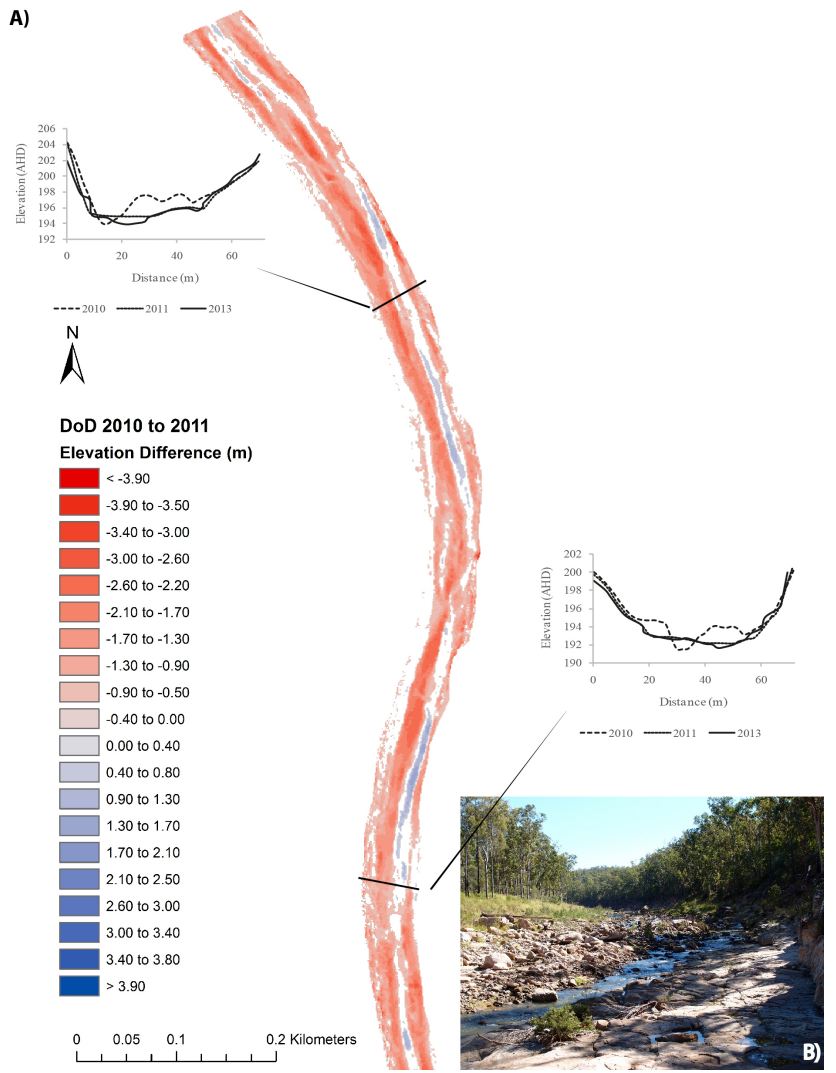

Figure 6. (a) Map of DEM of difference $\left(\mathrm{DoD}-{ }_{\min } \mathrm{LoD}=0.44\right)$ between the 2010 and 2011 lidar data at Murphys Creek (Fig. 2), due to the 2011 flood. Positive (blue) values indicate deposition and negative (red) values indicate erosion, units in metres. Flow is from top to bottom. Insets are temporal cross sections derived from 2010 and 2011 lidar (pre- and post-2011 flood) and 2013 DGPS survey data (post-2013 flood) showing the effects of the 2011 flood on channel cross-sectional area. (b) Upstream view of Murphys Creek highlighting the exposure of the bedrock straths exposed in the 2011 flood.

Table 4. Cross-sectional area changes due to the 2011 flood at each of the three study reaches. Cross sections were extracted approximately every channel width from the pre- and post-lidar in the three reaches (15-20 cross sections per reach).

\begin{tabular}{lccc}
\hline & $\begin{array}{c}\text { Mean cross- } \\
\text { sectional } \\
\text { area } 2010\left(\mathrm{~m}^{2}\right)\end{array}$ & $\begin{array}{c}\text { Mean cross- } \\
\text { sectional } \\
\text { area } 2011\left(\mathrm{~m}^{2}\right)\end{array}$ & $\begin{array}{c}\text { Change } \\
(\%)\end{array}$ \\
\hline Murphys Creek & 42 & 91 & 123 \\
Fifteen Mile Creek & 39 & 67 & 66 \\
Paradise Creek & 22 & 37 & 68 \\
\hline
\end{tabular}

and desktop) exhibit net erosion as a result of the 2011 flood, with an average loss of $0.4 \mathrm{~m}^{3} \mathrm{~m}^{-2}$ across the 13 reaches. A clear positive correlation between catchment area and normalised erosion exists for the responses to the 2011 flood (Fig. 7a-b; $R^{2}=0.72-0.74$ ) with a weaker inverse relation- ship between normalised erosion and channel slope (Fig. 7c$\mathrm{d} ; R^{2}=0.56$ ).

\subsection{A morphological classification in an erosional landscape}

The three field reaches exhibit poorly organised channel morphologies which are the direct result of the major flood in 2011. Generally, the reaches show a similar morphology despite the significant differences in contributing area and gradient. The Murphys Creek reach (largest catchment area) has the greatest degree of vertical variability, with Paradise Creek (Fig. 2) (smallest catchment area) exhibiting very little vertical (bed) variability. The three reaches have morphologies of alternating sequences of pools, riffles and bedrock steps but with significant plane-bed sections. The channel floor is mantled with cobble- to boulder-sized material, with stretches of each reach flowing over bedrock steps where 1-2 $\mathrm{m}$ of coarse bed material has been removed. Sediment sorting of individual channel units is very poor, with grain sizes ranging from sand to large boulders. Throughout the three reaches, the low-flow channels have high width-to-depth ratios and occur adjacent to elevated (recently exposed) bedrock straths or the bedrock valley margin on all outer bends. The morphology of Murphys Creek and Fifteen Mile Creek does not fit within the visually identifiable morphologies and physical characteristics of the Montgomery and Buffington (1997) and Thompson et al. (2006) classifications. All three of these reaches lie within the physical parameters of pool-riffle morphologies according to the classification of eastern Australian bedrock channels outlined by Thompson et al. (2006), yet they exhibit morphological characteristics generally found in steeper channels including bedrock steps and extensive plane-bed channel stretches. Whilst we cannot accurately constrain the nature of in-channel assemblages in the three reaches prior to the 2011 flood, the photographs and pre-lidar and post-lidar data point to significant reorganisation of the morphological units in this large-magnitude event (Figs. 45). In the following section we discuss the implications for such widespread rearrangement on both the evolution of such channels and their potential shift in process domains associated with extreme events.

\section{Discussion}

Confined semi-alluvial or bedrock-constrained rivers can only erode and incise the lithological substrate when the exposed bedrock (e.g. knickpoints) are subject to mechanical abrasion and plucking processes. In tectonically active settings it has been shown that incision rates decrease, associated with earthquake-produced sediment that shields the bedrock channels (Yanites et al., 2011). Yet, in tectonically passive settings with no earthquake-derived sediment and moderate to low relief, it is worth asking the question of what magnitude events remove the sediment cover and how 

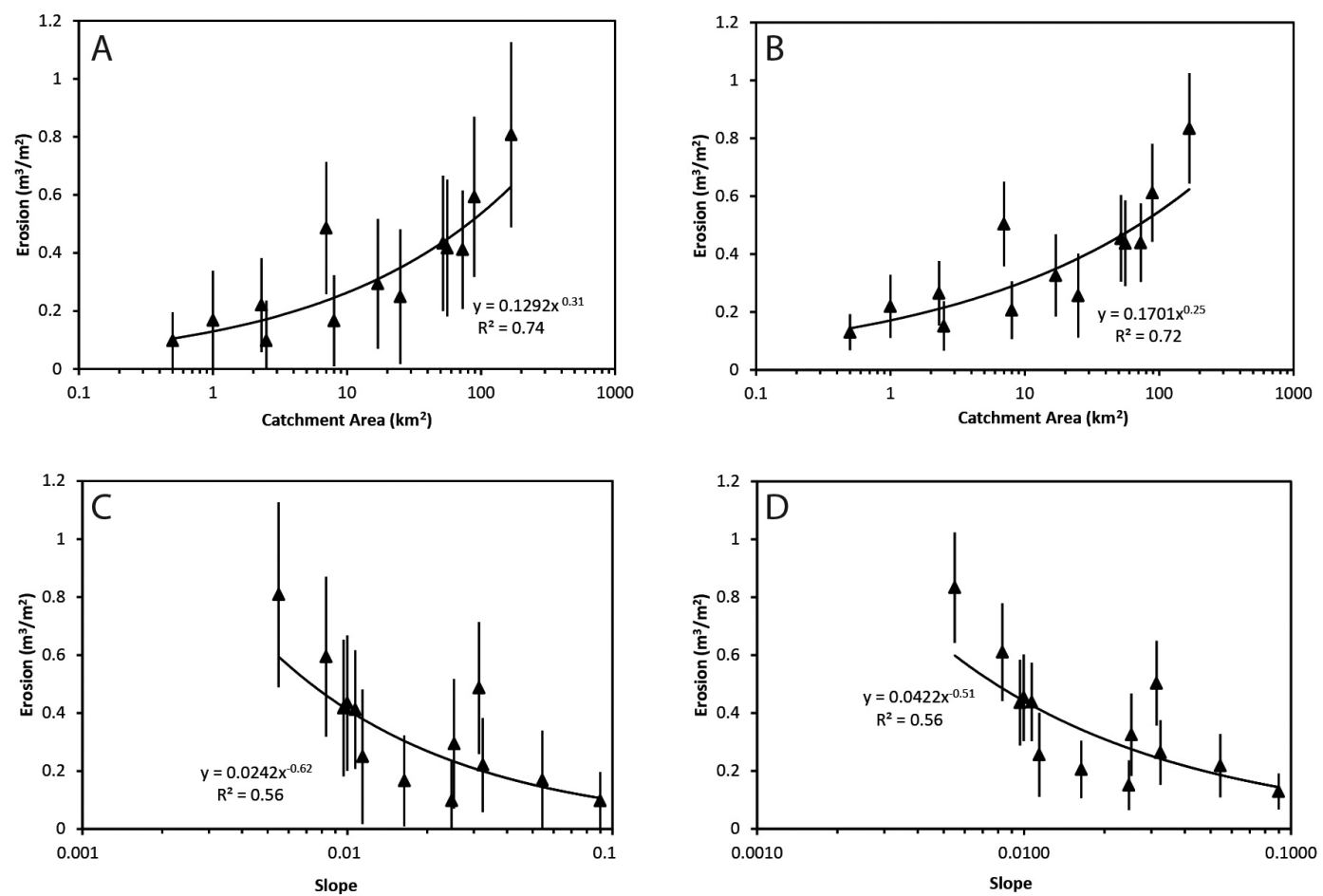

Figure 7. Relationship between catchment area and normalised erosion (a-b) and channel slope and normalised erosion (c-d) for 3 field and 10 desktop reaches in the upper Lockyer Valley, derived from DoDs between the 2010 and 2011 lidar data. Errors in (a) and (c) represent $0.44 \mathrm{~m}$ min LoD values whereas (b) and (d) represent $0.23 \mathrm{~m}$ min LoD.

often. Whilst the nature of such erosional events are stochastic (Snyder et al., 2003) their occurrence in settings such as the Great Dividing Range, where long-term erosion rates are very low, would be pivotal in providing the opportunity to erode the bedrock. Channels in such settings are often covered with coarse bed material, forming an assemblage of bedforms such as step pools and cascades forming "an alluvial overprint" (Carling, 2009), rarely mobilised in such hydrological variable settings. This cover effect has been the focus of much research over the last two decades (Sklar and Dietrich, 1998, 2001) and essentially demonstrates the role of an alluvial cover in limiting bedrock erosion (see Finnegan et al., 2014). Whilst we are not able to absolutely determine the pre-flood channel morphology for the upper Lockyer study area, the lidar-derived longitudinal profiles, cross sections and photographs all indicate much narrower semi-alluvial channel geometries and pronounced vertical variability in the longitudinal profile (presumed to be a function of organised coarse-grained bedforms such as step pools and cascades). The 2011 flood was of sufficient magnitude and exceeded critical thresholds such that in all field and desktop reaches the effect was a net loss of sediment. Such a loss in all reaches would suggest that such settings are flushed or are "floodcleaned" (using the classification scheme of Turowski et al., 2013) in such extreme events. Interestingly, however, the exposed or exhumed bedrock steps in the three field reaches all represent no more than $15 \%$ of the length of the current channel floor, within any given reach, inferring that most of the reach is still effectively covered by coarse-grained alluvium. In summary, we emphasise that the 2011 flood was an extreme event that initiated widespread loss of the alluvial cover and exposed bedrock steps that can now be attacked by abrasion and plucking processes.

\subsection{Morphological channel response to the January 2011 flood and subsequent channel recovery}

The catastrophic 2011 flood resulted in extensive channel stripping, with the wholesale transport of sediment, removal of mature riparian vegetation, and significant reductions in longitudinal and cross-sectional variability. This event constituted the largest flood on record for the catchment and one of the largest on record in Australia in terms of specific peak discharge (Thompson and Croke, 2013), overcoming entrainment thresholds for the entire grain-size population. The morphological response of the study reaches is consistent with a number of previous studies in which steep, confined channels experience decreases in morphological variability, channel widening and scour to form "U-shaped" channels (Nanson and Hean, 1985; Reinfelds and Nanson, 2004; Milan, 2012).

The degree of confinement evident in the study reaches also holds implications for the nature of sediment trans- 
port during the 2011 flood. The entrainment threshold calculations carried out in this study predicted the entrainment of the entire grain-size population. However, anecdotal evidence and recent deposits of extremely large boulders up to $4.82 \mathrm{~m}$ in diameter (Fig. 3) indicate that these empirical equations underestimate the effectiveness of catastrophic floods in such settings. The entrainment of unusually large clasts and comparatively voluminous bedload deposits during large floods is not unique, having been observed in other headwater drainage basins (Milan, 2012) and may be a function of non-Newtonian flow conditions associated with high concentrations of debris or simply be a function of scour on the downstream side. The study reaches of the upper Lockyer possess significantly lower gradients than channels typically associated with the hyper-concentrated flows (Costa, 1974). Nonetheless, the rapid onset of the 2011 flood and intensity of run-off resulted in extreme transmission speeds downstream, and this was coupled with hillslope failures and landslides which may have contributed to debris-type flows (Thompson and Croke, 2013).

\subsection{Modern channel morphology and classification}

The scale of catastrophic channel stripping during the 2011 flood and deposition of flood debris in a discontinuous cover along the narrow valley floor of the upper Lockyer has resulted in a wider more uniform channel morphology for all three field reaches. The stripping of alluvium down to bedrock in a number of locations has produced regular planated rock surfaces (Fig. 6b) and rock steps along the channel floor, which now dominate vertical variations in morphology and drops in channel gradient (Figs. 5-6). These morphologies do not adhere well to the existing classifications for mountainous streams outlined by Montgomery and Buffington (1997) and in the Australian context, as outlined by Thompson et al. (2006). The three study reaches are not particularly steep in terms of mountain streams, falling within the pool-riffle domain of the Thompson et al. (2006) morphological classification but which display long sections of featureless plane-bed morphology (e.g. Fifteen Mile and Paradise creeks, Fig. 5). The extent of erosion of the alluvial cover during the 2011 flood has resulted in significant bedrock control in the modern morphology, with bedrock abutting the low-flow channel of large stretches of the three reaches and exposed bedrock steps forming the major vertical variability. This degree of bedrock control over channel morphology is often attributed to steeper gradient reaches, highlighting the geomorphic effectiveness of the 2011 flood in changing the sediment supply and sediment transport capacity characteristics of the upper Lockyer.

Golden and Springer (2006) highlight the fact that the wholesale mobilisation of alluvium during large floods causes mixed alluvial-bedrock reaches to operate as bedrock reaches in the immediate aftermath of cover removal. The current morphologies observed in the upper Lockyer indi-
(A) Maturing, stable

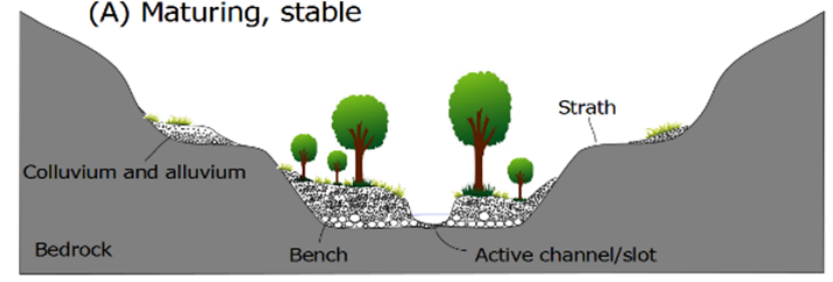

(B) Cleaning phase

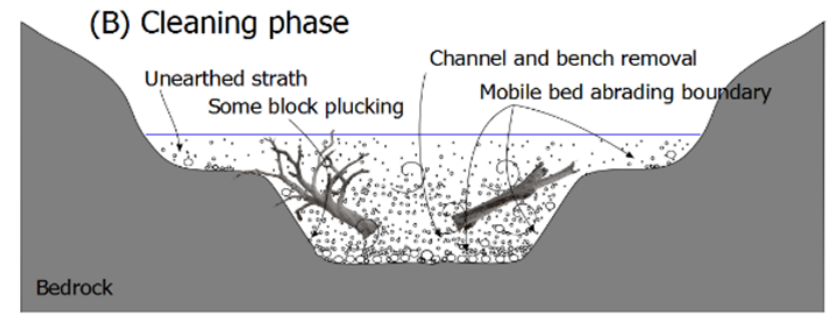

(C) Reset phase

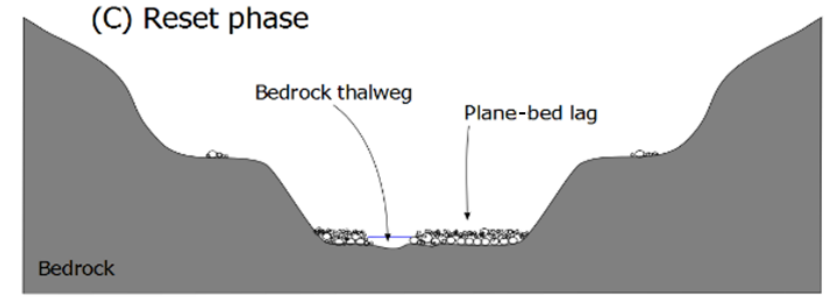

(D) Redevelopment phase

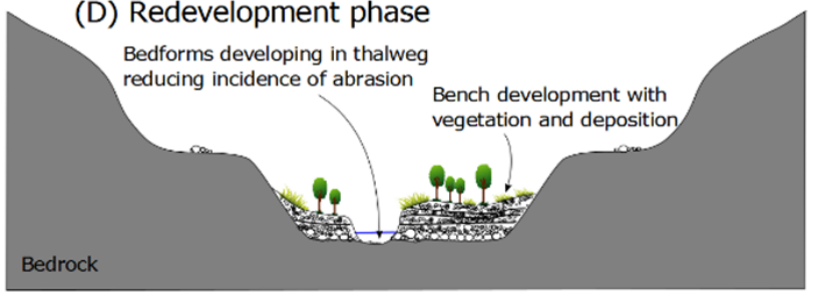

Figure 8. Schematic model for the evolution of semi-alluvial channels to an extreme event.

cate that the time for morphological recovery in terms of organisation of in-channel units has not yet been sufficient. However, the slight increase in long profile variability (e.g. reworking of coarse sediment into riffles/bars and minor rescouring of pools) during the smaller 2013 event suggests that the stream network has the capability of reshaping its erosional form potentially towards a more stable morphology. These post-2013 channel responses indicates that reorganisation of the alluvial overprint can occur in the intervening lower-frequency events (cf. Carling and Hurley, 1987) despite the 2011 flood resulting in the net removal of sediment within these semi-alluvial channels. These changes, which will occur according to the physical setting of individual reaches and available sediment and energy inputs, can be assumed to form more stable morphologies which reflect their physical setting and will be more closely aligned with existing frameworks of mountain stream classification. Con- 
straining the recovery time for such channels will form an important step in understanding the time required for such hydrologically variable systems to return to a stable state.

\subsection{An evolution model for bedrock-constrained channels}

A conceptual model of bedrock-constrained channel evolution in the Lockyer (Fig. 8) illustrates the change from a more stable channel morphology (pre-2011 flood form) to a flood-cleaned and reset channel (post-2011 extreme flood), and redeveloping channel bedforms (2013 and subsequent smaller floods). The model parallels the three phases of bed transport of Warburton (1992) but illustrates the mechanisms and timing of potential bedrock incision. The alluvial overprint of the stable morphology (Fig. 8a) prevents bedrock incision due to overprint feedback mechanisms or "overprint effect" (Turowski et al., 2013). This includes the pattern effect of the alluvial cross section shape (hydraulic geometry) on flow friction/distribution of shear across the channel (Turowski et al., 2008). In this case, in the stable configuration, a single-thread channel with a low width-to-depth ratio existed with alluvial benches, causing a narrowing of the channel. These coarse-grained alluvial benches afford bedrock cover and may be considered a bedform effect. The alluvial cover along the channel in the "stable" configuration (Fig. 8a) is also arranged in pool-riffle or step-pool bedforms, which exert different resistance to flow depending on stage height and are self-maintaining during small to medium events. The riffle bed forms also become armoured during the small to medium flood events. The amour or cover effect further protects the channel bed from the forces of water, saltation and suspended sediment (Seidl et al., 1994; Sklar and Dietrich, 1998, 2001). The cleaning phase (Fig. 8b) illustrates that the resistance produced by the pattern, bedform and cover effects is exceeded, resulting in full mobility of the coarse-grained alluvial cover. During this stage, which may only last for a relatively short period of the high-magnitude flood event, it is likely that the entire channel width is exposed to erosion from bedload abrasion and block plucking from boundary shear stress. The reset phase may commence during the receding limb of the high-magnitude event and during subsequent smaller flood events (Fig. 8c). Here a coarse lag of sediment deposits along the margin of the channel provides an armour layer. The thalweg remains relatively free of alluvial cover, enabling further bedrock erosion. Over time and an accumulation by flood events, lateral benches develop and exert a pattern and bedform effect, thereby reducing bedrock erosion (Fig. 8d). Coarse sediment accumulates in the inner channel slot, acting as erosion tools until it is reworked into bedforms such as riffles and steps, providing a stable bed and stopping any further bedrock erosion until the next thresholdexceeding event.

Bedrock channel evolution models have focused on bedaveraged vertical incision when quantifying the effects of tools and cover (e.g. Sklar and Dietrich, 1998) or the effects of widespread hillslope instability on the production of cover material (Hovius and Stark, 2006). Finnegan et al. (2007) differentiated between slot-averaged incision and bed-averaged incision so as to account for cross section variation in incision rates and therefore interaction between sediment supply and channel shape. This was further enforced by Nelson and Seminara's (2011) bedrock evolution model, showing that, for vertically incising bedrock channels, the cross section shape is strongly controlled by the history of sediment supply. While data from this study cannot convey information on the sediment supply history, they do show the effect of the extreme flood on flushing the channel of coarse-grained bars and benches, unearthing the bedrock straths before leaving a lag of cobbles and boulders (cobble plane bed Fig. 8b, c) interspersed by planar and stepped bedrock sections. Further, as depicted in Fig. 4, the active channel bed has been laterally relocated within the larger valley floor. This may have implications for models such as that of Finnegan et al. (2007), in which a single focus point (slot) in the channel was emphasised for vertical incision compared to data presented here which show the active channel or slot being moved across the valley bottom, leading to a new slot for bedrock erosion during the time between the flood cleaning and resetting events.

\section{Conclusions}

Field survey data and desktop-based analyses for 13 reaches with catchment areas ranging from 0.5 to $168 \mathrm{~km}^{2}$ show that the predicted discharge for the 2011 event ranged from 415 to $933 \mathrm{~m}^{3} \mathrm{~s}^{-1}$, with unit stream power estimates of up $1077 \mathrm{~W} \mathrm{~m}^{-2}$. The absolute return interval for these small catchments is difficult to constrain, but the nearby gauge records and anecdotal evidence suggests the 2011 flood was a rare and an extreme event. Estimated entrainment relationships predict the mobility of the entire grain-size population, and field data suggest the localised mobility of boulders up to $4.82 \mathrm{~m}$ in diameter. Morphological change has been quantified with repeat lidar data that showed all 13 reaches were areas of net erosion via extensive scouring of coarse alluvium with a strong positive relationship between catchment area and normalised erosion. The extensive scouring in the 2011 flood decreased bed level variance of the coarse-grained cover with the exposure of planar bedrock surfaces, marginal bedrock straths and bedrock steps, along with the formation of plane-bed cobble morphology. The current nature and distribution of channel morphological units does not conform to previous classifications of mountain river systems but illustrates a change in process domain due to changes in the sediment supply and sediment transport capacity relationship induced by the 2011 flood. Post-flood field data suggest a slight recovery in bed level variance, and hence bedform (re)development, as a result of the smaller 2013 flood. This highlights the significance of extreme events like the 
January 2011 flood for resetting the morphology of such semi-alluvial systems. Long-term rates of landscape lowering/bedrock incision must be sensitive to the frequency and magnitude of such cover-removing events, and the 2011 flood has now exposed bedrock steps within these settings, providing an opportunity for bedrock erosion.

Acknowledgements. This project was funded through an Australian Research Council funded linkage project (LP120200093). We would like to thank the industry partners in this project, landholders in the upper Lockyer catchment and James Daley for assistance in the field. We would also like to thank Paul Carling and Jens Turowski for providing constructive feedback which has improved the quality of the manuscript.

Edited by: A. Stroeven

\section{References}

Baker, V. R.: Stream-channel response to floods, with examples from central Texas, Geol. Soc. Am. Bull., 88, 1057-1071, 1977.

Baker, V. R. and Kale, V. S.: The role of extreme floods in shaping bedrock channels, in: Rivers over rock, in: Fluvial processes in bedrock channels, edited by: Tinkler, K. J. and Wohl, E. E., Geol. Soc. Am. Bull., Washington D.C., USA, doi:10.1029/GM107p0153, 1998.

Bathurst, J. C.: Critical conditions for bed material movement in steep, boulder-bed streams, Erosion and Sedimentation in the Pacific Rim, Proceedings of the Corvallis Symposium, Corvallis, Oregon, USA, 3-7 August 1987, IAHS Publication No. 165, 1987.

BMT WBM Pty Ltd.: Technical Report on the Lockyer Valley Floods of 9-11 January 2011, Queensland Floods Commission of Inquiry, Local Government Association of Queensland Limited, N. I. Collins, Brisbane,32 pp., 2011.

Buffington, J. M., Woodsmith, R. D., Booth, D. B., and Montgomery, D. R.: Fluvial processes in Puget Sound rivers and the Pacific Northwest, in: Restoration of Puget Sound Rivers, edited by: Montgomery, D. R., Bolton, S., Booth, D. E., and Wall, L., University of Washington Press, Seattle, WA, 46-78, 2003.

Bunte, K. and Abt, S. R.: Sampling surface and subsurface particlesize distribution in wadable gravel- and cobble-bed streams for analyses in sediment transport, hydraulics, and streambed monitoring, RMRS-GTR-74, Rocky Mountain Research Station, Forest Service, Fort Collins, CO, USA, 428 pp., 2001.

Bureau of Meteorology: Special Climate Statement 24 - National Climate Centre: Frequent heavy rain events in late 2010/early 2011 lead to widespread flooding aross eastern Australia, Special Climate Statement, Melbourne, Australia, 28 pp., 2011.

Bureau of Meteorology: Special Climate Statement 44 - Extreme Rainfall and Flooding in Coastal Queensland and New South Wales, Melbourne, Australia, 18 pp., 2013.

Carling, P.: Geomorphology and sedimentology of the Lower Mekong River, in: The Mekong: Biophysical Environment of an International River Basin, edited by: Campbell, I. C., Academic Press, New York, 77-111, 2009.
Carling, P. A. and Hurley, M. A.: A time-varying stochastic model of the frequency and magnitude of bed load transport events in two small trout streams, in: Sediment Transport in Gravel-bed Rivers, edited by: Thorne, C. R., Bathurst, J. C., and Hey, R. D., John Wiley \& Sons, Chichester, UK, 897-920, 1987.

Charlton, M. E., Large, A. R. G., and Fuller, I. C.: Application of airborne LiDAR in river environments: the River Coquet, Northumberland, UK, Earth Surf. Proc. Land., 28, 299-306, 2003.

Costa, J. E.: Response and recovery of a Piedmont watershed from tropical storm Agnes, June 1972, Water Resour. Res., 10, 106112, 1974.

Costa, J. E. and O'Connor, J. E.: Geomorphically effective floods, in: Natural and Anthropogenic Influences in Fluvial Geomorphology, AGU 89, Washington, D.C., 45-56, 1995.

Croke, J., Todd, P., Thompson, C., Watson, F., Denham, R., and Ghanal, G.: The use of multi-spectral temporal LiDAR to assess basin-scale erosion and deposition following the catastrophic January 2011 Lockyer flood, SE Queensland, Australia, Geomorphology, 184, 111-126, 2013.

Erskine, W. D. and Warner, R. F.: Further assessment of flood- and drought-dominated regimes in south-eastern Australia, Aust. Geogr., 29, 257-261, 1998.

Finlayson, B. L. and McMahon, T. A.: Australia vs. the World: a comparative analysis of streamflow characteristics, in: Fluvial Geomorphology of Australia, edited by: Warner, R. F., Academic Press, Sydney, Australia, 373 pp., 1988.

Finnegan, N. J., Sklar, L. S., and Fuller, T. K.: Interplay of sediment supply, river incision, and channel morphology revealed by the transient evolution of an experimental bedrock channel, J. Geophys. Res., 112, F03S11, doi:10.1029/2006JF000569, 2007.

Finnegan, N. J., Schumer, R., and Finnegan, S.: A signature of transience in bedrock river incision rates over timescales of $10^{4}-10^{7}$ years, Nature, 505, 391-394, doi:10.1038/nature 12913 , 2014.

Fuller, I. C.: Geomorphic impacts of a 100-year flood: Kiwitea Stream, Manawatu catchment, New Zealand, Geomorphology, 98, 84-95, 2008.

Geological Survey of Queensland: Queensland Geological Mapping (Polygonised Vector) Digital Data, Geological Survey of Queensland, http://mines.industry.qld.gov.au/geoscience/ (last access: December 2014), 2011.

Golden, L. A. and Springer, G. S.: Channel geometry, median grain size, and stream power in small mountain streams, Geomorphology, 78, 64-76, 2006.

Grove, J. R., Croke, J., and Thompson, C.: Quantifying different riverbank erosion processes during an extreme flood event, Earth Surf. Proc. Land., 38, 1393-1406, doi:10.1002/esp.3386, 2013.

Halwas, K. L. and Church, M.: Channel units in small, high gradient streams on Vancouver Island, British Columbia, Geomorphology, 43, 243-256, 2002.

Hickin, E. J.: River channel changes: retrospect and prospect, in: Modern and Ancient Fluvial Systems, Blackwell Publishing Ltd. Oxford, 59-83, 2009.

Hovius, N. and Stark, C. P.: Landslide-driven erosion and topographic evolution of active mountain belts, in: Landslides from Massive Rock Slope Failure, edited by: Evans, S. G., Scarascia Mugnozza, G., Strom, A., and Hermanns, R. L., NATO Science Series, Springer, the Netherlands, 573-590, 2006. 
Howard, A. D., Dietrich, W. D., and Seidl, M. A.: Modelling fluvial erosion on regional to continental scales, J. Geophys. Res., 99, 971-986, 1994.

Jansen, J. D.: Flood magnitude-frequency and lithologic control on bedrock river incision in post-orogenic terrain, Geomorphology, 82, 39-57, 2006.

Kirkup, H., Brierley, G., Brooks, A., and Pitman, A.: Temporal variability of climate in south-eastern Australia: a reassessment of flood- and drought-dominated regimes, Aust. Geogr., 29, 241255, 1998.

Komar, P. D. and Carling, P. A.: Grain sorting in gravel-bed streams and the choice of particle sizes for flow-competence evaluations, Sedimentology, 38, 489-502, 1991.

Lague, D.: Reduction of long-term bedrock incision efficiency by short-term alluvial cover intermittency, J. Geophys. Res., 114, F02011, doi:10.1029/2008JF001210, 2010.

Meshkova, L. V., Carling, P. A., and Buffin-Bélanger, T: Nomenclature, complexity, semi-alluvial channels, and sediment fluxdriven bedrock erosion, in: Gravel Bed Rivers: Processes, Tools, Environments, 2nd Edn., edited by: Church, M., Biron, P. M., and Roy, A. G., Hoboken, NJ, USA, John Wiley \& Sons, 424-431, 2012.

Meyer-Peter, E. and Müller, R.: Formulas for bed-load transport, in: IAHSR 2nd Meeting, Stockholm, Appendix 2, 39-65, 1948.

Milan, D. J.: Geomorphic impact and system recovery following an extreme flood in an upland stream: Thinhope Burn, northern England, UK, Geomorphology, 138, 319-328, 2012.

Miller, A. J.: Valley morphology and boundary conditions influencing spatial patterns of flood flow, in: Natural and Anthropogenic Influences in Fluvial Geomorphology, Washington, D.C., USA, AGU 89, 57-81, 1995.

Montgomery, D. R. and Buffington, J. M.: Channel-reach morphology in mountain drainage basins, Bull. Geol. Soc. Am., 109, 596-611, 1997.

Nanson, G. C.: Episodes of vertical accretion and catastrophic stripping: a model of disequilibrium floodplain development, Geol. Soc. Am. Bull., 97, 1467-1475, 1986.

Nanson, G. C. and Hean, D.: The West Dapto flood of February 1984: rainfall characteristics and channel changes, Aust. Geogr., 16, 249-258 1985.

Nelson, P. A. and Seminara, G.: Modeling the evolution of bedrock channel shape with erosion from saltating bed load, Geophys. Res. Lett., 38, L17406, doi:10.1029/2011GL048628, 2011.

Reinfelds, I and Nanson, G. C.: Aspects of the hydrogeomorphology of Illawarra streams: Implications for planning and design of urbanising landscapes, Wetlands (Australia), 21, 220-236, 2004.

Rustomji, P., Bennett, N., and Chiew, F.: Flood variability east of Australia's Great Dividing Range, J. Hydrol., 374, 196-208, 2009.

Seidl, M. A., Dietrich, W. E., and Kirchner, J. W.: Longitudinal profile development into bedrock; an analysis of Hawaiian channels, J. Geol., 102, 457-474, 1994.

SEQ Water: Report on the Operation of Somerset Dam and Wivenhoe Dam, January 2011 Flood Event, Seqwater, 1180 pp., 2011.

Shields, A. F.: Application of similarity principles and turbulence research to bed-load movement, Mitteil. Preuss. Versuchsan. Wasserb. Schiffb., 26, 5-24, 1936.
Sklar, L. S. and Dietrich, W. E.: River longitudinal profiles and bedrock incision models: stream power and the influence of sediment supply, in: Rivers Over Rock: Fluvial Processes in Bedrock Channels, edited by: Tinkler, K. J. and Wohl, E. E., Geophys. Monogr. Ser., vol. 107, AGU, Washington, D.C., 237-260, 1998.

Sklar, L. S. and Dietrich, W. E.: Sediment and rock strength controls on river incision into bedrock, Geology, 29, 1087-1090, 2001.

Snyder, N. P., Whipple, K. X., Tucker, G. E., and Merritts, D. J.: Importance of a stochastic distribution of floods and erosion thresholds in the bedrock river incision problem, J. Geophys. Res., 108, 2117, doi:10.1029/2001JB001655, 2003.

Thompson, C. J. and Croke, J.: Geomorphic effects, flood power, and channel competence of a catastrophic flood in confined and unconfined reaches of the upper Lockyer valley, southeast Queensland, Australia, Geomorphology, 197, 156-169, 2013.

Thompson, C. J., Croke, J., Ogden, R., and Wallbrink, P.: A morpho-statistical classification of mountain stream reach types in southeastern Australia, Geomorphology, 81, 43-65, 2006.

Tinkler, K. and Wohl, E. E.: Field studies of bedrock channels, in: Rivers Over Rock: Fluvial Processes in Bedrock Channels, edited by: Tinkler, K. J. and Wohl, E. E., Geophys. Monogr., 107, 261-277, 1998.

Toone, J., Rice, S. P., and Piégay, H.: Spatial discontinuity and temporal evolution of channel morphology along a mixed bedrockalluvial river, upper Drôme River, southeast France: contingent responses to external and internal controls, Geomorphology, 205, 5-16, doi:10.1016/j.geomorph.2012.05.033, 2014.

Turowski, J. M., Lague, D., and Hovius, N.: Cover effect in bedrock abrasion: A new derivation and its implications for the modeling of bedrock channel morphology, J. Geophys. Res., 112, F04006, doi:10.1029/2006JF000697, 2007.

Turowski, J. M., Hovius, N., Meng-Long, H., Lague, D., and MenChiang, C.: Distribution of erosion across bedrock channels, Earth, Surf. Proc. Landforms, 33, 353-363, 2008.

Turowski, J. M., Lague, D., Wilcock, P. R., and Hovius, N.: Response of bedrock channel width to tectonic forcing: Insights from a numerical model, theoretical considerations, and comparison with field data, J. Geophys. Res., 114, F03016, doi:10.1029/2008JF001133, 2009.

Turowski, J. M., Badoux, A., Leuzinger, J., and Hegglin, R.: Large floods, alluvial overprint, and bedrock erosion, Earth, Earth Surf. Proc. Land., 38, 947-958, doi:10.1002/esp.3341, 2013.

Warburton, J.: Observations of bed load transport and channel bed changes in a proglacial mountain stream, Arct. Alp. Res., 24, 195-203, 1992.

Wheaton, J. M, Brasington, J., Darby, S. E., and Sear, D. A.: Accounting for uncertainty in DEMs from repeat topographic surveys: improved sediment budgets, Earth Surf. Process. Landforms, 35, 136-156, 2010.

Wohl, E. E.: Review of effects of large floods in resistant-boundary channels, in: Developments in Earth Surface Processes, edited by: Habersack, H. P. and Massimo, R., Elsevier, 181-211, doi:10.1016/S0928-2025(07)11125-1, 2007.

Wohl, E. E. and Merritt, D. M.: Bedrock channel morphology, Geol. Soc. Am. Bull., 113, 1205-1212, 2001.

Wohl, E. E. and Merritt, D. M.: Reach-scale channel geometry of mountain streams, Geomorphology, 93, 168-185, 2008.

Wolman, M. G.: A method of sampling coarse river-bed material, Trans., Am. Geophys. Union, 35, 6, 1954. 
Wolman, M. G. and Gerson, R.: Relative scales of time and effectiveness of climate in watershed geomorphology, Earth Surf. Proc. Land., 3, 189-208, 1978.

Wolman, M. G. and Miller, J. P.: Magnitude and frequency of forces in geomorphic processes, J. Geol., 69, 54-74, 1960.
Yanites, B. J., Tucker, G. E., Hsu, H.-L., Chen, C.-C., Chen, Y.G., and Mueller, K. J.: The influence of sediment cover variability on long-term river incision rates: an example from the Peikang River, Central Taiwan, J. Geophys. Res., 116, F03016, doi:10.1029/2010JF001933, 2011. 